\title{
PERBEDAAN KETEPATAN ANTARA RUMUS JOHNSON TOSHACH, RUMUS MODIFIKASI JOHNSON MENURUT SYAHRIR, RUMUS NISWANDER DAN RUMUS SML DALAM MENAKSIR BERAT BADAN LAHIR DI RUANG BERSALIN RSUD KOTA MATARAM
}

\author{
Dina Fithriana* \\ *Pengajar Sekolah Tinggi Ilmu Kesehatan (STIKES) Mataram \\ Email: dinafithriana@ymail.com
}

\begin{abstract}
ABSTRAK
Angka kematian ibu dan angka kematian bayi di Indonesia relative tinggi, yakni 25 kasus kematian bayi per 1.000 kelahiran dan jumlah ibu melahirkan yang meninggal dunia sebanyak 228 kasus per 1.000 kelahiran. Kematian bayi terbanyak disebabkan oleh Bayi Berat Lahir Rendah (BBLR). Perlu dipertimbangkan ketepatan dalam penaksiran berat badan janin, akan tetapi belum ada suatu metoda pun yang berhasil membuat taksiran berat badan lahir dengan tepat. penelitian ini dilakukan di ruang bersalin RSUD Kota Mataram dengan tujuan untuk mengetahui bagaimana perbedaan ketepatan antara rumus Johnson Toshach, rumus modifikasi Johnson menurut Syahrir, rumus Niswander dan rumus SML (Subagio, Masengi, Loho) dalam menaksir berat badan lahir.

Rancangan penelitian adalah deskriptif komparatif. Populasi pada penelitian ini adalah semua ibu yang melahirkan di ruang bersalin RSUD Kota Mataram dengan jumlah sampel sebanyak 49 oang. Intrumen yang digunakan adalah pengkuran dan perhitungan.

Hasil penelitian menunjukkan tidak terdapat perbedaan yang signifikan antara berat badan lahir dengan rumus Johnson Toshach $(\mathrm{p}=0,115)$. Terdapat perbedaan yang signifikan antara berat badan lahir dengan rumus modifikasi Johnson menurut Syahrir $(\mathrm{p}=0,000)$. Terdapat perbedaan yang signifikan antara berat badan lahir dengan rumus Niswander $(p=0,000)$. Tidak terdapat perbedaan yang signifikan antara berat badan lahir dengan rumus SML (Subagio, Masengi, Loho) ( $\mathrm{p}=0,974)$.

Rumus SML (Subagio, Masengi, Loho) adalah yang terdekat dengan berat badan lahir bayi dengan mean difference 41.74461 dan nilai probabilitas 0,974 . Sehingga rumus SML (Subagio, Masengi, Loho) dapat digunakan sebagai alternatif cara menaksir berat badan lahir sebagai bahan pertimbangan pengambilan keputusan dan penanganan persalinan.
\end{abstract}

Kata-kata kunci: Taksiran berat badan lahir, berat badan lahir, rumus Johnson Toshach, rumus modifikasi Johnson menurut Syahrir, rumus Niswander dan rumus SML (Subagio, Masengi, Loho)

\section{PENDAHULUAN}

Kementerian Koordinator Kesejahteraan Rakyat (Kemenko Kesra) menilai angka kematian bayi dan ibu melahirkan di Indonesia relatif tinggi. Berdasarkan data yang dimiliki kementerian ini, jumlah bayi yang meninggal di Indonesia mencapai 34 kasus per 1.000 kelahiran. Jumlah tersebut lebih tinggi dari angka Millenium Development Goals (MDG's), yakni 25 kasus per 1.000 kelahiran. Sementara jumlah ibu melahirkan yang meninggal dunia sebanyak 228 kasus per 1.000 kelahiran (Sarmun, 2012). 
Penyebab kematian bayi baru lahir (Neonatus) yang terbanyak disebabkan oleh kegawatdaruratan dan penyulit pada masa Neonatus, salah satunya Bayi Berat Lahir Rendah (BBLR). Angka kejadian BBLR di Indonesia sangat bervariasi antara satu daerah dengan daerah lain, yaitu berkisar antara 9\%-30\%, hasil studi di 7 daerah Multicenter diperoleh angka BBLR dengan rentan 2,1\%-17,2\% (Wijaya, 2009).

Kematian perinatal pada kelahiran dengan berat badan rendah dan kesakitan akibat berat badan lahir yang besar merupakan suatu masalah tersendiri dalam kesehatan perinatal dan penatalaksanaan persalinan. Taksiran Berat Badan Janin (TBBJ) intra uterin mempunyai arti penting dalam penatalaksanaan persalinan. Ketepatan penaksiran berat badan lahir, baik secara pengukuran tinggi fundus uteri (TFU) ataupun cara lainnya akan mempengaruhi ketepatan penatalaksanaan persalinan dan hasilnya sehingga diharapkan dapat mengurangi kematian dan kesakitan pada persalinan (Cunningham, 2006).

Bagi penolong persalinan, berat badan bayi mempunyai arti yang sangat penting dalam menentukan saat rujukan, sedangkan bagi obstetrikus, taksiran berat badan bayi diperlukan ketika memutuskan tindakan induksi persalinan ataupun resiko sesaria yang direncanakan. Terdapat berbagai cara untuk menentukan taksiran berat badan bayi, yaitu: dengan palpasi uterus, pemeriksaan ultrasonografi, dengan pengukuran diameter biparietal, pengukuran tinggi fundus uteri maupun pengukuran lingkaran perut. Selain itu penggunaan USG telah umum dijumpai pada rumah sakit yang telah memiliki fasilitas dan sarana pelayanan kesehatan yang cukup modern terutama di kota besar (Pilliteri, 2002).

Penaksiran berat janin dalam suatu persalinan masih dipandang perlu oleh banyak ahli kebidanan, juga para peneliti kesehatan masyarakat. Meskipun demikian, belum ada suatu metoda pun yang berhasil membuat taksiran berat badan janin tepat. Pada beberapa rumah sakit, masih dilakukan taksiran berat badan janin intra uterin dengan pengukuran tinggi fundus uteri. Ketepatan taksiran berat badan janin baik melalui pengukuran tinggi fundus uteri ataupun cara lain akan mempengaruhi penatalaksanaan persalinan (Subagio P., Masengi J.A., Taniowas Loho M., 2000).

Beberapa rumus untuk mengetahui perkiraan berat badan lahir bayi, di antaranya adalah rumus Johnson Toshach, rumus Modifikasi Johnson menurut Syahrir, rumus Niswander dan rumus SML (Subagio, Masengi, Loho). Johnson dan Toshach (1954) menggunakan suatu metode untuk menaksir berat janin dengan pengukuran (TFU) tinggi fundus uteri, yaitu mengukur jarak antara tepi atas simfisis pubis sampai puncak fundus uteri dengan mengikuti lengkungan uterus, memakai pita pengukur serta melakukan pemeriksaan dalam (vaginal toucher) untuk mengetahui penurunan bagian terendah.

Syahrir dan kawan-kawan pada tahun 2001 di Makasar melakukan pengukuran dengan mendapatkan modifikasi rumus Johnson yang disederhanakan oleh Niswander. Dalam mendapatkan rumus tersebut, Syahrir dan kawan-kawan melakukan penelitian dengan menggunakan jangka panggul terhadap 100 ibu inpartu yang akan melahirkan di kamar bersalin RSB Siti Fatimah yang memenuhi kriteria inklusi dan ekslusi dengan presentasi kepala untuk mencari modifikasi rumus Johnson.

Subagio P., Masengi J.A., Taniowas Loho M. di RSUP Manado melakukan penelitian terhadap $200 \mathrm{ibu}$ hamil yang masuk kamar bersalin mengenai hubungan berat badan lahir dengan jarak simfisis dan fundus dan beberapa anthropometri ibu (lingkaran perut, lingkaran lengan, lengan kiri atas, berat badan ibu, tinggi badan ibu). Mereka mengemukakan 
bahwa jarak simfisis fundus dan tinggi badan merupakan variabel yang memberikan konstribusi yang optimal pada rumusan estimasi berat badan lahir dan memperoleh rumusan estimasi berat badan lahir dan menamakan rumus ini dengan rumus SML (Subagio, Masengi, Loho) (Rosmina S., Masengi J.A., Taniowas Loho M., 2001).

Hasil penelitian Subagio P., Masengi J.A., Taniowas Loho M. tersebut menunjukkan bahwa pada kelompok berat lahir 3000-3999 gram, rumus SML (Subagio, Masengi, Loho) lebih baik dari pada rumus Johnson sebab lebih dekat dengan BBL sebenarnya. Adapun rumus SML (Subagio, Masengi, Loho) ini belum diterapkan penggunaannya dan direkomendasikan untuk di uji coba sebagai salah satu cara untuk mengestimasi berat badan lahir serta perlu adanya tindak lanjut dari penelitian sebelumnya (Rosmina S., Masengi J.A., Taniowas Loho M., 2001).

Pada bulan Februari 2005 sampai September 2006, Julianty K., dkk melakukan penelitian tentang perbandingan akurasi taksiran berat badan janin antara rumus Johnson Tohsach dan modifikasi rumus Johnson menurut Syahrir. Hasilnya menyatakan bahwa rumus Johnson lebih baik sebab memiliki akurasi lebih tinggi, yaitu sebesar 70,7\% dibanding modifikasi rumus JohnsonSyahrir yang hanya sebesar $65 \%$.

Penelitian lain yang dilakukan oleh Prasetyowati, Firda Fibrila dan Martini (2009) tentang Perbandingan Hasil Tafsiran Berat Janin menurut Johnson Tohsach dan Niswander dengan Berat Badan Lahir pada Ibu Inpartu di BPS Kabupaten Lampung Utara. Hasil penelitian menunjukkan bahwa rumus Johnson Tohsach lebih baik dalam menaksir berat badan lahir dibandingkan dengan rumus Niswander.

Rumah Sakit Umum Daerah Kota Mataram merupakan rumah sakit rujukan untuk seluruh puskesmas di wilayah kota mataram dimana jumlah persalinan dari bulan Januari sampai bulan Desember 2018 mencapai 3188 persalinan. Dalam menaksir berat badan lahir bayi di Rumah Sakit Umum Daerah Kota Mataram menggunakan rumus Johnson Toshach dan berdasarkan hasil pemeriksaan ultrasonografi. Rumus modifikasi Johnson menurut Syahrir, rumus Niswander dan rumus SML (Subagio, Masengi, Loho) belum diterapkan penggunaannya di rumuah sakit tersebut.

Oleh karena terdapat beberapa rumus untuk mengetahui taksiran berat badan lahir bayi, maka penelitian ini dilakukan di ruang bersalin Rumah Sakit Umum Daerah Kota Mataram dengan tujuan untuk mengetahui bagaimana perbedaan ketepatan antara rumus Johnson Toshach, rumus modifikasi Johnson menurut Syahrir, rumus Niswander dan rumus SML (Subagio, Masengi, Loho) dalam menaksir berat badan lahir sebagai bahan pertimbangan pengambilan keputusan dalam penanganan persalinan.

\section{METODE PENELITIAN}

Rancangan penelitian ini merupakan penelitian deskriptif komparatif yakni suatu metode penelitian yang dilakukan dengan cara membandingkan persamaan dan perbedaan sebagai fenomena untuk mencari faktor-faktor apa, atau situasi bagimana yang menyebabkan timbulnya suatu peristiwa tertentu (Notoatmodjo, 2005). Dari segi waktu bersifat prospektif karena penelitian ini bersifat forward looking. Istilah prospektif ini disebut juga dengan istilah cohort atau Longitudinal kedepan (Budiarto 2004).

Sampel pada penelitian ini adalah semua ibu yang melahirkan di ruang bersalin RSUD Kota Mataram pada saat penelitian dilakukan yang telah memenuhi kriteria inklusi penelitian yang berjumlah 49 orang. 
Adapun Instrumen pada penelitian ini adalah:
a. Wawancara
digunakan untuk mengetahui umur dan paritas.

b. Pita ukur (metlin) untuk mengukur tinggi fundus uteri.

c. Microtoise Staturmeter untuk mengukur tinggi badan.

d. Rumus Johnson Toshach untuk menghitung taksiran berat badan lahir:

1) Bila bagian terendah janin masuk pintu atas panggul:

$\mathrm{TBBJ}=(\mathrm{TFU}-11) \times 155$

2) Bila bagian terendah janin sejajar atau belum masuk pintu atas panggul:

TBBJ $=($ TFU -12$) \times 155$

e. Rumus Modifikasi Johnson Menurut Syahrir untuk menghitung taksiran berat badan lahir:

TBBJ $=($ TFU - 13) $151+190$ gram

f. Rumus Niswander untuk menghitung taksiran berat badan lahir:

TBBJ = 1,2 (TFU - 7,7) x 100 gram

g. Rumus SML (Subagio, Masengi, Loho) untuk menghitung taksiran berat badan lahir:

TBBJ $($ gram $)=119,26 \quad($ JSF $)+$ 12,16(TB) - 2487,93

Keterangan: JSF $=$ Jarak Simfisi Fundus

JSF $=$ TFU (Tinggi Fundus Uteri)

$\mathrm{TB}=$ Tinggi Badan

h. Timbangan berat badan bayi untuk menimbang berat badan lahir bayi.

i. Rumus untuk menghitung ketepatan berat badan lahir adalah:

Selisih TBBL rumus ${ }^{~}{ }{ }^{m}$

Selisih tertinggi TBBL dari semua rumus

Keterangan:

TBBL $=$ Taksiran berat badan lahir

j. Data tentang ketepatan taksiran berat badan lahir diolah secara deskriptif dan ditabulasi menggunakan distribusi frekuensi dengan skoring:

1) Ketepatan baik = tingkat kesalahan $0-25 \%$
2) Ketepatan cukup = tingkat kesalahan 26-50\%

3) Ketepatan kurang = tingkat kesalahan $51-75 \%$

4) Ketepatan sangat kurang = tingkat kesalahan 76-100\%

(Hidayat, 2009)

\section{HASIL PENELITIAN}

1. Data Umum (Karakteristik Responden) a. Tinggi Fundus Uteri

(TFU) Responden

Dalam penelitian ini TFU ibu hamil dikelompokkan menjadi tiga kelompok, yaitu <26 cm 26-37 cm dan $>37 \mathrm{~cm}$, adapun perinciannya dapat dilihat pada tabel berikut:

Tabel 1.1 Distribusi Responden Berdasarkan Tinggi Fundus Uteri

\begin{tabular}{|l|l|l|l|}
\hline & $\begin{array}{l}\text { Tinggi } \\
\text { Fundus } \\
\text { Uteri }\end{array}$ & $\begin{array}{l}\text { Jumlah } \\
(\text { orang) }\end{array}$ & $\begin{array}{l}\text { Persentase } \\
(\%)\end{array}$ \\
\hline 1 & $<26 \mathrm{~cm}$ & 0 & 0 \\
\hline 2 & $26-37 \mathrm{~cm}$ & 49 & 100 \\
\hline 3 & $>37 \mathrm{~cm}$ & 0 & 0 \\
\hline \multicolumn{2}{|l}{ Total } & 49 & 100 \\
\hline
\end{tabular}

Dari tabel di atas dapat dilihat bahwa dari 49 orang responden seluruhnya mempunyai tinggi fundus uteri antara 26 sampai 37 $\mathrm{cm}$. Tidak terdapat responden yang mempunyai ukuran tinggi fundus uteri di bawah $26 \mathrm{~cm}$ dan di atas 37 $\mathrm{cm}$.

b. Tinggi Badan Responden

Berdasarkan hasil penelitian didapatkan seluruh responden memiliki tinggi badan $\geq 145 \mathrm{~cm}$, untuk lebih jelasnya dapat dilihat pada tabel berikut:

Tabel 1.2 Distribusi Responden Bedasarkan Tinggi Badan

\begin{tabular}{|l|l|l|l|}
\hline $\begin{array}{l}\mathrm{N} \\
\mathrm{o}\end{array}$ & $\begin{array}{l}\text { Tinggi Badan } \\
\text { Ibu Hamil }\end{array}$ & $\begin{array}{l}\text { Jumlah } \\
\text { (orang) }\end{array}$ & $\begin{array}{l}\text { Persentase } \\
(\%)\end{array}$ \\
\hline 1 & $<145 \mathrm{~cm}$ & 0 & 0 \\
\hline 2 & $\geq 145 \mathrm{~cm}$ & 49 & 100 \\
\hline \multicolumn{2}{|l}{ Total } & 49 & 100 \\
\hline
\end{tabular}


Dari tabel di atas dapat dilihat bahwa seluruh responden yang berjumlah 49 orang mempunyai tinggi badan di atas $145 \mathrm{~cm}$.

c. Umur Responden

Berdasarkan hasil penelitian umur responden berkisar antara 18 sampai 35 tahun, untuk lebih rinci dapat dilihat pada tabel berikut:

Tabel 1.3 Distribusi Responden Berdasarkan Umur

\begin{tabular}{|l|l|l|l|}
\hline No & Umur & $\begin{array}{l}\text { Jumlah } \\
\text { (orang) }\end{array}$ & $\begin{array}{l}\text { Persentase } \\
(\%)\end{array}$ \\
\hline 1 & $<20$ tahun & 1 & $2,04 \%$ \\
\hline 2 & $20-35$ tahun & 48 & $97,96 \%$ \\
\hline 3 & $>35$ tahun & 0 & 0 \\
\hline \multicolumn{2}{|c|}{ Total } & 49 & 100 \\
\hline
\end{tabular}

Dari tabel di atas dapat dilihat bahwa hampir seluruh responden berumur antara 20 sampai 35 tahun, yaitu: sebanyak 48 orang $(97,96 \%)$ dan hanya 1 orang $(2,04 \%)$ responden berumur di bawah 20 tahun, tidak terdapat responden yang berumur di atas 35 tahun.

d. Paritas Responden

Responden pada penelitian ini adalah ibu bersalin yang memiliki paritas dibawah 4, untuk lebih rincinya dapat dilihat pada grafik berikut:

Tabel 1.4 Distribusi Respoden Berdasarkan Paritas

\begin{tabular}{|l|l|l|l|}
\hline No & Paritas & $\begin{array}{l}\text { Jumlah } \\
\text { (orang) }\end{array}$ & $\begin{array}{l}\text { Persentase } \\
(\%)\end{array}$ \\
\hline 1 & $\begin{array}{l}\text { Paritas 1 } \\
\text { (Primipara) }\end{array}$ & 27 & $55,10 \%$ \\
\hline 2 & $\begin{array}{l}\text { Paritas 2 } \\
\text { (Multipara) }\end{array}$ & 18 & $36,74 \%$ \\
\hline 3 & $\begin{array}{l}\text { Paritas 3 } \\
\text { (Multipara) }\end{array}$ & 4 & 8,16 \\
\hline \multicolumn{2}{|l|}{ Total } & 49 & 100 \\
\hline
\end{tabular}

Dari tabel di atas dapat dilihat bahwa sebagian besar responden baru pertama kali melahirkan (primipara), yaitu sebanyak 27 orang $(55,10 \%)$, terdapat sebagian kecil responden yang sudah melahirkan sebanyak 3 kali (multipara), yaitu sebanyak 4 orang $(8,16 \%)$ dan 18 orang $(36,74 \%)$ responden lainnya sudah melahirkan sebanyak 2 kali.

2. Data Khusus

a. Taksiran Berat Badan Lahir Menurut Rumus Johnson Toshach, Rumus Modifikasi Johnson Menurut Syahrir, Rumus Niswander dan Rumus SML (Subagio, Masengi, Loho).

Berdasarkan hasil perhitungan dengan menggunakan rumus Johnson Toshach, rumus Modifikasi Johnson menurut Syahrir, rumus Niswander dan rumus SML (Subagio, Masengi, Loho) didapatkan taksiran berat badan lahir. Data mengenai taksiran berat badan lahir dapat dilihat pada tabel berikut:

Tabel 2.1 Taksiran Berat Badan Lahir Menurut Rumus Johnson Toshach, Rumus Modifikasi Johnson Menurut Syahrir, Rumus Niswander dan Rumus SML (Subagio, Masengi, Loho)

\begin{tabular}{|l|l|l|l|l|l|l|l|}
\hline \multirow{2}{*}{ No } & \multirow{2}{*}{ Rumus } & \multicolumn{2}{|c|}{$\begin{array}{c}<2500 \\
\text { gram }\end{array}$} & \multicolumn{2}{|c|}{$\begin{array}{c}2500-4000 \\
\text { gram }\end{array}$} & \multirow{2}{*}{$\mathrm{N}$} & \multirow{2}{*}{$(\%)$} \\
\cline { 3 - 6 } & $\mathrm{n}$ & $(\%)$ & $\mathrm{n}$ & $(\%)$ & & \\
\hline 1 & Johnson Toshach & 4 & 8.16 & 45 & 91.84 & 49 & 100 \\
\hline 2 & $\begin{array}{l}\text { Modifikasi } \\
\text { Johnson Menurut } \\
\text { Syahrir }\end{array}$ & 4 & 8.16 & 45 & 91.84 & 49 & 100 \\
\hline 3 & Niswander & 4 & 8.16 & 45 & 91.84 & 49 & 100 \\
\hline 4 & $\begin{array}{l}\text { SML (Subagio, } \\
\text { Masengi, Loho) }\end{array}$ & 1 & 2.04 & 48 & 97.96 & 49 & 100 \\
\hline
\end{tabular}

Berdasarkan tabel di atas dapat dilihat bahwa hasil taksiran berat badan lahir berdasarkan rumus Johnson Toshach, rumus modifikasi Johnson menurut Syahrir, rumus Niswander dan rumus SML (Subagio, Masengi, Loho) sebagian besar berkisar antara 2500 gram sampai 4000 gram. Rumus Johnson Toshach, rumus modifikasi Johnson menurut Syahrir dan rumus Niswander menaksir berat badan lahir <2500 gram masing-masing sebanyak 4 responden $(8,16 \%)$, 
sedangkan rumus SML (Subagio, Masengi, Loho) menaksir hanya 1 responden $(2,04 \%)$ yang memiliki berat badan lahir <2500 gram.

b. Hasil Penimbangan Berat Badan Lahir Bayi

Berdasarkan hasil penelitian didapatkan bahwa seluruh berat badan lahir bayi berkisar antara 2500 gram sampai 4000 gram. Ini selaras dengan hasil taksiran berat badan janin berdasarkan rumus Johnson Toshach, rumus modifikasi Johnson menurut Syahrir, rumus Niswander dan rumus SML (Subagio, Masengi, Loho) yang sebagian besar berkisar antara 2500 gram sampai 4000 gram.

c. Ketepatan Taksiran Berat Badan Lahir

lahir ditentukan berdasarkan persentase tingkat kesalahan dalam perhitungan taksiran berat badan lahir. Ketepatan rumus Johnson Toshach, rumus modifikasi Johnson menurut Syahrir, rumus Niswander dan rumus SML (Subagio, Masengi, Loho) dalam menaksir berat badan lahir dapat dilihat pada gambar berikut:

Tabel 2.2 Ketepatan Taksiran Berat Badan Lahir

\begin{tabular}{|c|c|c|c|c|c|c|c|c|c|}
\hline \multirow{2}{*}{ No } & \multirow{2}{*}{ Rumus } & \multicolumn{2}{|c|}{ Baik } & \multicolumn{2}{|c|}{ Cukup } & \multicolumn{2}{|c|}{ Kurang } & \multicolumn{2}{|c|}{$\begin{array}{l}\text { Sangat } \\
\text { Kurang }\end{array}$} \\
\hline & & $\mathrm{n}$ & $\%$ & $\mathrm{n}$ & $\%$ & $\mathrm{n}$ & $\%$ & $\mathrm{~N}$ & $\%$ \\
\hline 1 & $\begin{array}{l}\text { Johnson } \\
\text { Toshach }\end{array}$ & $\begin{array}{l}2 \\
7\end{array}$ & $\begin{array}{l}55.1 \\
0\end{array}$ & $\begin{array}{l}1 \\
4\end{array}$ & 28.57 & 7 & 14.29 & 1 & 2.04 \\
\hline 2 & $\begin{array}{l}\text { Modifikasi } \\
\text { Johnson } \\
\text { Menurut } \\
\text { Syahrir }\end{array}$ & $\begin{array}{l}2 \\
7\end{array}$ & $\begin{array}{l}55.1 \\
0\end{array}$ & $\begin{array}{l}1 \\
4\end{array}$ & 28.57 & 7 & 14.29 & 1 & 2.04 \\
\hline 3 & Niswander & $\begin{array}{l}1 \\
8\end{array}$ & $\begin{array}{l}46.1 \\
5 \\
\end{array}$ & $\begin{array}{l}1 \\
3\end{array}$ & 33.33 & 4 & 10.26 & 4 & 10.26 \\
\hline 4 & $\begin{array}{l}\text { SML } \\
\text { (Subagio, } \\
\text { Masengi, } \\
\text { Loho) }\end{array}$ & $\begin{array}{l}3 \\
6\end{array}$ & $\begin{array}{l}73.4 \\
7\end{array}$ & 9 & 18.37 & 3 & 6.12 & 1 & 2.04 \\
\hline
\end{tabular}

Keterangan:

$\mathrm{n}=$ Jumlah responden (orang)

$\%=$ Persentase Ketepatan Taksiran Berat Badan Lahir

Berdasarkan tabel 2.2 dapat dilihat bahwa rumus SML (Subagio,
Masengi, Loho) memiliki ketepatan taksiran berat badan lahir lebih baik dibandingkan dengan rumus Johnson Toshach, rumus modifikasi Johnson menurut Syahrir dan rumus Niswander. Ini terlihat dari hasil taksiran berat badan lahir berdasarkan rumus SML (Subagio, Masengi, Loho) yang menunjukkan ketepatan baik sebesar $73.47 \%$.

Dibandingkan dengan hasil taksiran berat badan lahir berdasarkan rumus Johnson Toshach yang dan rumus modifikasi Johnson menurut Syahrir yang menunjukkan ketepatan baik masing-masing sebesar 55,10\%, serta rumus Niswander yang menunjukkan ketepatan baik sebesar 46,15\%.

d. Analisa Perbedaan Ketepatan Antara Rumus Johnson Toshach, Rumus Modifikasi Johnson Menurut Syahrir, Rumus Niswander Dan Rumus SML (Subagio, Masengi, Loho) Dalam Menaksir Berat Badan Lahir Di Ruang Bersalin RSUD Kota Mataram

\section{1) Uji ANOVA}

Uji ANOVA (Analysis Of Variance) dilakukan apakah berat badan lahir bayi, rumus Johnson Toshach, rumus modifikasi Johnson menurut Syahrir, rumus Niswander dan rumus SML (Subagio, Masengi, Loho) mempunyai rata-rata (mean) yang sama.

\section{Tabel 2.3 Uji ANOVA}

\begin{tabular}{|l|l|l|l|l|}
\hline & Df & $\begin{array}{l}\text { Mean } \\
\text { Square }\end{array}$ & F & Sig. \\
\hline $\begin{array}{l}\text { Between } \\
\text { Groups }\end{array}$ & 4 & $\begin{array}{l}816204.93 \\
6\end{array}$ & $\begin{array}{l}7.03 \\
3\end{array}$ & .000 \\
\hline $\begin{array}{l}\text { Within } \\
\text { Groups }\end{array}$ & 240 & $\begin{array}{l}116054.45 \\
5\end{array}$ & & \\
\hline Total & 244 & & & \\
\hline
\end{tabular}

Dari tabel di atas terlihat bahwa $\mathrm{F}$ hitung adalah 7,033 dengan nilai probabilitas 0,000 . Karena nilai probabilitas $<0,05$, 
maka $\mathrm{H}_{0}$ ditolak atau terdapat perbedaan antara rata-rata dari berat badan lahir bayi, rumus Johnson Toshach, rumus modifikasi Johnson menurut Syahrir, rumus Niswander dan rumus SML (Subagio, Masengi, Loho).

2) Post Hoc Tests

Setelah diketahui bahwa terdapat perbedaan diantara berat badan lahir bayi, rumus Johnson Toshach, rumus modifikasi Johnson menurut Syahrir, rumus Niswander dan rumus SML (Subagio, Masengi, Loho), Post Hoc Tests ditujukan untuk menganalisa mana saja diantara berat badan lahir bayi, rumus Johnson Toshach, rumus modifikasi Johnson menurut Syahrir, rumus Niswander dan rumus SML (Subagio, Masengi, Loho) yang berbeda dan tidak berbeda atau dalam hal ini sejauh mana kedekatan antara berat badan lahir bayi, rumus Johnson Toshach, rumus modifikasi Johnson menurut Syahrir, rumus Niswander dan rumus SML (Subagio, Masengi, Loho).

Tabel 2.4 Uji Post Hoc Tests.

\begin{tabular}{|c|c|c|c|c|c|c|}
\hline \multirow{2}{*}{$\begin{array}{l}\mathbf{N} \\
\mathbf{o}\end{array}$} & \multirow{2}{*}{$\begin{array}{l}\text { (I) } \\
\text { Variab } \\
\text { el }\end{array}$} & \multirow{2}{*}{ (J) Variabel } & \multirow{2}{*}{$\begin{array}{l}\text { Mean } \\
\text { Difference } \\
\text { (I-J) }\end{array}$} & \multirow{2}{*}{ Sig. } & \multicolumn{2}{|c|}{$\begin{array}{l}\text { 95\% Confidence } \\
\text { Interval }\end{array}$} \\
\hline & & & & & $\begin{array}{l}\text { Lower } \\
\text { Bound }\end{array}$ & $\begin{array}{l}\text { Upper } \\
\text { Bound }\end{array}$ \\
\hline 1 & $\begin{array}{l}\text { Berat } \\
\text { Badan } \\
\text { Lahir } \\
\text { Bayi } \\
\end{array}$ & $\begin{array}{l}\text { Rumus Johnson } \\
\text { Toshach }\end{array}$ & 166.18367 & .115 & - 22.9914 & 355.3588 \\
\hline 2 & $\begin{array}{l}\text { Berat } \\
\text { Badan } \\
\text { Lahir } \\
\text { Bayi }\end{array}$ & $\begin{array}{l}\text { Rumus } \\
\text { Modifikasi } \\
\text { Johnson } \\
\text { Menurut Syahrir }\end{array}$ & $203.86939(*)$ & .028 & 14.6943 & 393.0445 \\
\hline 3 & $\begin{array}{l}\text { Berat } \\
\text { Badan } \\
\text { Lahir } \\
\text { Bayi }\end{array}$ & $\begin{array}{l}\text { Rumus } \\
\text { Niswander }\end{array}$ & $321.18367\left(^{*}\right)$ & .000 & $\begin{array}{l}132.008 \\
6\end{array}$ & 510.3588 \\
\hline 4 & $\begin{array}{l}\text { Berat } \\
\text { Badan } \\
\text { Lahir } \\
\text { Bayi }\end{array}$ & $\begin{array}{l}\text { Rumus SML } \\
\text { (Subagio, } \\
\text { Masengi, Loho) }\end{array}$ & 41.74461 & .974 & $\begin{array}{l}- \\
147.430 \\
5\end{array}$ & 230.9197 \\
\hline
\end{tabular}

Keterangan: Jika terdapat tanda “*” di angka mean difference, maka terdapat perbedaan yang signifikan. Jika tidak terdapat tanda “*”, maka perbedaan tidak signifikan.

Dari tabel di atas dapat dijabarkan sebagai berikut:

a) Analisa perbedaan antara berat badan lahir dengan rumus Johnson Toshach

(1)Mean Difference (mean berat badan lahir - mean rumus Johnson Toshach) $=166.18367$

(2)Nilai probabilitas 0,115 . Karena nilai probabilitas $>0,05$, maka $\mathrm{H}_{0}$ diterima atau tidak terdapat perbedaan yang signifikan antara berat badan lahir dengan rumus Johnson Toshach

b) Analisa perbedaan antara berat badan lahir dengan rumus modifikasi Johnson menurut Syahrir

(1)Mean Difference (mean berat badan lahir - mean rumus modifikasi Johnson menurut Syahrir) = 203.86939

(2)Nilai probabilitas 0,028 . Karena nilai probabilitas $<0,05$, maka $\mathrm{H}_{0}$ ditolak atau terdapat perbedaan yang signifikan antara berat badan lahir dengan rumus modifikasi Johnson menurut Syahrir

c) Analisa perbedaan antara berat badan lahir dengan rumus Niswander

(1)Mean Difference (mean berat badan lahir - mean rumus Niswander) = 321.18367

(2)Nilai probabilitas 0,000 . Karena nilai probabilitas $<0,05$, maka $\mathrm{H}_{0}$ ditolak atau terdapat perbedaan 
yang signifikan antara berat badan lahir dengan rumus Niswander

d) Analisa perbedaan antara berat badan lahir dengan rumus SML (Subagio, Masengi, Loho)

(1) Mean Difference (mean berat badan lahir - mean rumus SML (Subagio, Masengi, Loho)) = 41.74461

(2) Nilai probabilitas 0,974 . Karena nilai probabilitas $>0,05$, maka $\mathrm{H}_{0}$ diterima atau tidak terdapat perbedaan yang signifikan antara berat badan lahir dengan rumus SML (Subagio, Masengi, Loho)

Dari penjabaran di atas dapat disimpulkan bahwa rumus SML (Subagio, Masengi, Loho) adalah yang terdekat dengan berat badan lahir bayi. Ini dapat dilihat dari nilai mean difference yang hanya 41.74461 dan merupakan nilai terkecil dibandingkan dengan rumus lainnya serta nilai probabilitas 0,974 $(>0,05)$ yang berarti $\mathrm{H}_{0}$ diterima atau tidak terdapat perbedaan yang signifikan antara berat badan lahir dengan rumus SML (Subagio, Masengi, Loho).

Rumus Johnson Toshach merupakan rumus terdekat kedua dengan berat badan lahir bayi setelah rumus SML (Subagio, Masengi, Loho) dengan mean difference 166.18367, rumus modifikasi Johnson menurut Syahrir dengan mean difference 203.86939 terdekat ketiga dengan berat badan lahir bayi dan rumus Niswander terdekat keempat dengan mean difference 321.18367 .

\section{PEMBAHASAN}

a. Taksiran Berat Badan Lahir Menurut Rumus Johnson Toshach, Rumus Modifikasi Johnson Menurut Syahrir, Rumus Niswander dan Rumus SML (Subagio, Masengi, Loho).

Berdasarkan hasil penelitian dapat dilihat bahwa hasil taksiran berat badan lahir berdasarkan rumus Johnson Toshach, rumus modifikasi Johnson menurut Syahrir, rumus Niswander dan rumus SML (Subagio, Masengi, Loho) sebagian besar berkisar antara 2500 gram sampai 4000 gram. Rumus Johnson Toshach, rumus modifikasi Johnson menurut Syahrir dan rumus Niswander menaksir berat badan lahir $<2500$ gram masing-masing sebanyak 4 responden $(8,16 \%)$, sedangkan rumus SML (Subagio, Masengi, Loho) menaksir hanya 1 responden $(2,04 \%)$ yang memiliki berat badan lahir $<2500$ gram.

Hal ini disebabkan oleh rumus Johnson Toshach, rumus modifikasi Johnson menurut Syahrir dan rumus Niswander hanya menggunakan tinggi fundus uteri sebagai parameter perhitungan taksiran berat badan janin, yang membedakan hanya konstanta pada masing-masing rumus. Rumus SML (Subagio, Masengi, Loho) selain menggunakan tinggi fundus uteri sebagai parameter untuk menaksir berat badan lahir, juga menggunakan tinggi badan ibu yang memberikan konstribusi optimal pada rumusan taksiran.

b. Hasil Penimbangan Berat Badan Lahir Bayi

Berdasarkan hasil penelitian didapatkan seluruh berat badan lahir bayi berkisar antara 2500 gram sampai 4000 gram. Ini selaras dengan hasil taksiran berat badan janin berdasarkan rumus Johnson Toshach, rumus modifikasi Johnson menurut Syahrir, rumus Niswander dan rumus SML 
(Subagio, Masengi, Loho) yang sebagian besar berkisar antara 2500 gram sampai 4000 gram.

Berat badan lahir antara 2500 gram sampai 4000 gram merupakan berat badan lahir normal. Menurut Depkes RI (2005) bayi baru lahir normal adalah bayi yang lahir dengan umur kehamilan 37 minggu sampai 42 minggu dan berat lahir 2500 gram sampai 4000 gram. Bayi yang dilahirkan kurang dari ukuran normal dapat berdampak negatif terhadap perkembangan organ-organ tubuhnya, sementara bayi yang memiliki berat yang berlebih justru bisa membahayakan sang ibu saat melahirkan.

c. Ketepatan Taksiran Berat Badan Lahir Berdasarkan hasil penelitian didapatkan bahwa rumus SML (Subagio, Masengi, Loho) memiliki ketepatan taksiran berat badan lahir lebih baik dibandingkan dengan rumus Johnson Toshach, rumus modifikasi Johnson menurut Syahrir dan rumus Niswander. Ini terlihat dari hasil taksiran berat badan lahir berdasarkan rumus SML (Subagio, Masengi, Loho) yang menunjukkan ketepatan baik sebesar $73.47 \%$. Dibandingkan dengan hasil taksiran berat badan lahir berdasarkan rumus Johnson Toshach yang dan rumus modifikasi Johnson menurut Syahrir yang menunjukkan ketepatan baik masing-masing sebesar $55,10 \%$, serta rumus Niswander yang menunjukkan ketepatan baik sebesar $46,15 \%$.

Dari hasil penelitian ini didapatkan bahwa adanya kecenderungan rumus SML (Subagio, Masengi, Loho) dengan parameter jarak simpisis fundus dan tinggi badan lebih baik dibandingkan dengan rumus Johnson Toshach, rumus modifikasi Johnson menurut Syahrir dan rumus Niswander yang menggunakan variabel tinggi fundus uteri. Jarak simfisis fundus dan tinggi badan merupakan variabel yang memberikan konstribusi yang optimal pada rumusan estimasi berat badan lahir (Subagio P., Masengi J.A., Taniowas Loho M., 2000).

d. Analisa Perbedaan Ketepatan Antara Rumus Johnson Toshach, Rumus Modifikasi Johnson Menurut Syahrir, Rumus Niswander Dan Rumus SML (Subagio, Masengi, Loho) Dalam Menaksir Berat Badan Lahir Di Ruang Bersalin RSUD Kota Mataram

Berdasarkan uji ANOVA didapatkan bahwa $\mathrm{F}$ hitung adalah 7,033 dengan nilai probabilitas 0,000 . Karena nilai probabilitas $<0,05$, maka $\mathrm{H}_{0}$ ditolak atau terdapat perbedaan antara rata-rata dari berat badan lahir bayi, rumus Johnson Toshach, rumus modifikasi Johnson menurut Syahrir, rumus Niswander dan rumus SML (Subagio, Masengi, Loho).

Setelah diketahui bahwa terdapat perbedaan diantara berat badan lahir bayi, rumus Johnson Toshach, rumus modifikasi Johnson menurut Syahrir, rumus Niswander dan rumus SML (Subagio, Masengi, Loho), dilakukan Post Hoc Tests yang bertujuan untuk menganalisa mana saja diantara berat badan lahir bayi dan rumus - rumus tersebut yang berbeda dan tidak berbeda.

Dari hasil Post Hoc Tests didapatkan:

1) Perbedaan berat badan lahir dengan rumus Johnson Toshach

Hasil penelitian diperoleh nilai probabilitas 0,115 . Karena nilai probabilitas $>0,05$, maka $\mathrm{H}_{0}$ diterima atau tidak terdapat perbedaan yang signifikan antara berat badan lahir dengan rumus Johnson Toshach. Pada Taksiran berat badan janin berdasarkan rumus Johnson Toshach disesuaikan dengan penurunan kepala janin ke dalam rongga panggul sehingga hasil pengukuran mendekati berat 
badan lahir jika dibandingkan dengan rumus modifikasi Johnson menurut Syahrir dan rumus Niswander.

Ini sesuai dengan hasil penelitian Julianty K., dkk pada bulan Februari 2005 sampai September 2006 yang hasilnya menyatakan bahwa rumus Johnson lebih baik sebab memiliki akurasi lebih tinggi, yaitu sebesar $70,7 \%$ dibanding modifikasi rumus Johnson-Syahrir yang hanya sebesar 65\%. Hasil penelitian Prasetyowati, Firda Fibrila dan Martini pada tahun 2009 menunjukkan bahwa rumus Johnson Tohsach lebih baik dalam menaksir berat badan lahir dibandingkan dengan rumus Niswander.

Berbagai hasil penelitian ini menambah dukungan terhadap penggunaan rumus Johnson Toshach dalam menaksir berat badan lahir. Rumus Johnson Toshach merupakan rumus yang banyak digunakan untuk mengetahui taksiran berat janin dalam peraktek keperawatan maternitas dan kebidanan. Hanya saja dalam penggunaan rumus ini perlu diperhatikan beberapa faktor yang berpengaruh terhadap pengukuran atau taksiran dan diperkirakan tidak dapat dikoreksi seperti tumor rahim, hidraamnion, plasenta previa dan kehamilan ganda (Prasetyowati, Firda Fibrila dan Martini, 2009).

2) Perbedaan berat badan lahir dengan rumus modifikasi Johnson menurut Syahrir

Hasil penelitian diperoleh nilai probabilitas 0,028 . Karena nilai probabilitas $<0,05$, maka $\mathrm{H}_{0}$ ditolak atau terdapat perbedaan yang signifikan antara berat badan lahir dengan rumus modifikasi Johnson menurut Syahrir. Ini sesuai dengan hasil penelitian Julianty K., dkk pada bulan Februari 2005 sampai September 2006 yang hasilnya menyatakan rumus modifikasi Johnson menurut Syahrir memiliki akurasi yang hanya sebesar $65 \%$ dan menerangkan kesesuaian penghitungan taksiran berat badan lahir bayi dengan menggunakan rumus Johnson Toshach dibandingkan dengan rumus modifikasi Johnson menurut Syahrir.

Salah satu kelemahan dari rumus modifikasi Johnson menurut Syahrir adalah hanya menggunakan tinggi fundus uteri sebagai parameter dalam menaksir berat badan lahir yang tentunya keakuratannya dipengaruhi berbagai macam faktor seperti berat badan ibu, lingkar lengan atas ibu, letak janin, dan jumlah cairan amnion. Alat ukur yang digunakan untuk mengukur tinggi fundus uteri juga berperan penting dalam hasil taksiran berat badan lahir berdasarkan rumus modifikasi Johnson menurut Syahrir.

Berdasarkan penelitian yang dilakukan Prima Deri Pella T, Sri Tadjuddin Chalid, IMS. Murah Manoe tahun 2002 yang meneliti tentang aplikasi modifikasi rumus Johnson menurut Syahrir dengan menggunakan jangka panggul dan pita non elastik, didapatkan nilai akurasi dari pada jangka panggul $(96,5 \%)$ lebih tinggi dari pada nilai akurasi pita non elastik $(94,3 \%)$ dalam menaksir berat badan lahir. Sehingga perlu dipertimbangkan menggunakan jangka panggul untuk mengukur tinggi fundus uteri.

3) Perbedaan berat badan lahir dengan rumus Niswander

Hasil penelitian diperoleh nilai probabilitas 0,000 . Karena nilai probabilitas $<0,05$, maka $\mathrm{H}_{0}$ ditolak atau terdapat perbedaan yang 
signifikan antara berat badan lahir dengan rumus Niswander. Ini sesuai dengan hasil penelitian Prasetyowati, Firda Fibrila dan Martini pada tahun 2009 yang menunjukkan bahwa terdapat perbedaan yang signifikan antara rata-rata hasil taksiran berat badan lahir berdasarkan rumus Niswander dengan berat badan lahir bayi.

Rumus Niswander merupakan salah satu rumus yang banyak digunakan untuk mengetahui taksiran berat janin dalam praktik keperawatan maternitas dan kebidanan selain rumus Johnson Toshach. Akan tetapi, berdasarkan hasil penelitian penggunaan rumus Niswander dalam menentukan taksiran berat badan lahir diperoleh hasil perhitungan yang lebih rendah dibandingkan dengan berat badan lahir bayi, sehingga rumus Niswander perlu dipertimbangkan dalam penggunaannya untuk menaksir berat badan janin karena kurang dapat mendeteksi adanya berat bayi besar.

4) Perbedaan berat badan lahir dengan rumus SML (Subagio, Masengi, Loho)

Hasil penelitian diperoleh nilai probabilitas 0,974. Karena nilai probabilitas $>0,05$, maka $\mathrm{H}_{0}$ diterima atau tidak terdapat perbedaan yang signifikan antara berat badan lahir dengan rumus SML (Subagio, Masengi, Loho). Ini sesuai dengan Hasil penelitian Subagio P., Masengi J.A., Taniowas Loho M. Yang menunjukkan bahwa pada kelompok berat lahir 30003999 gram, rumus SML (Subagio, Masengi, Loho) lebih baik dari pada rumus Johnson Toshach sebab lebih dekat dengan berat badan lahir.

Dari analisa Post Hoc Tests juga dapat disimpulkan bahwa rumus SML (Subagio, Masengi,
Loho) adalah yang terdekat dengan berat badan lahir bayi. Ini dapat dilihat dari nilai mean difference yang hanya 41.74461 dan merupakan nilai terkecil dibandingkan dengan rumus lainnya serta nilai probabilitas $0,974(>0,05)$ yang berarti $\mathrm{H}_{0}$ diterima atau tidak terdapat perbedaan yang signifikan antara berat badan lahir dengan rumus SML (Subagio, Masengi, Loho).

Taksiran berat janin yang banyak digunakan di Indonesia adalah dengan menggunakan pengukuran fundus uteri yang tentunya keakuratannya dipengaruhi berbagai macam faktor seperti berat badan ibu, lingkar lengan atas ibu, letak janin, dan jumlah cairan amnion. Faktor yang paling berpengaruh terhadap hasil perhitungan taksiran berat janin adalah pengukuran tinggi fundus uteri secara benar.

Faktor lain yang berpengaruh terhadap ketepatan taksiran berat janin ialah faktor ibu yang sejak awal kehamilan memang sudah gemuk maka pada kehamilan tinggi fundus uterinya bisa lebih tinggi dari pada ukuran ibu dengan berat normal atau ibu yang sebelum hamilnya kurus. Pada ibu-ibu yang gemuk, adanya tumpukan lemak dibawah kulit perut tentunya akan menambah besar ukuran tinggi fundus, padahal bayi yang dilahirkan kemudian belum tentu lebih besar dari ibu-ibu yang berat badan awalnya normal.

Selain faktor kegemukan, kemungkinan yang lain adalah adanya variasi yang cukup lebar dari tinggi badan ibu. Ibu hamil yang pendek dengan janin yang besar akan mempunyai kesan perut yang lebih membuncit dibanding ibu hamil yang lebih tinggi. Sehingga 
hasil pengukuran tinggi fundus uterinya bias lebih tinggi pula. Faktor-faktor antropometri di dalam rongga pelvis ibu juga bisa menjadi variabel pengganggu yang tidak bisa dikendalikan. Variabel pengganggu lainnya adalah perbedaan umur kehamilan yang ekstrim, janin kembar atau gemili serta janin cacat misalnya hidrosefalus.

Pada taksiran berat badan lahir berdasarkan rumus SML (Subagio, Masengi, Loho) menggunakan jarak simfisis fundus dan tinggi badan yang merupakan parameter penting dan memberikan konstribusi yang optimal dalam menaksir berat badan lahir, sehingga hasil pengukuran mendekati berat badan lahir jika dibandingkan dengan rumus Johnson Toshach, rumus modifikasi Johnson menurut Syahrir dan rumus Niswander yang hanya menggunakan parameter tinggi fundus uteri.

Selama ini dalam praktek keperawatan maternitas dan kebidanan rumus yang umum digunakan untuk menaksir berat badan lahir adalah rumus Johnson Toshach, rumus modifikasi Johnson menurut Syahrir dan rumus Niswander, sedangkan rumus SML (Subagio, Masengi, Loho) belum banyak diterapkan penggunaannya.

Berdasarkan hasil penelitian didapatkan bahwa rumus SML (Subagio, Masengi, Loho) lebih tepat dalam menaksir berat badan lahir dibandingkan dengan ruumus Johnson Toshach, rumus modifikasi Johnson menurut Syahrir dan rumus Niswander, sehingga rumus SML (Subagio, Masengi, Loho) dapat digunakan sebagai alternatif cara menaksir berat badan lahir sebagai bahan pertimbangan pengambilan keputusan dan penanganan persalinan.

\section{KESIMPULAN}

Berdasarkan pembahasan hasil penelitian dapat ditarik kesimpulan sebagai berikut :

1. Hasil taksiran berat badan lahir berdasarkan rumus Johnson Toshach, rumus modifikasi Johnson menurut Syahrir, rumus Niswander dan rumus SML (Subagio, Masengi, Loho) sebagian besar berkisar antara 2500 gram sampai 4000 gram

2. Seluruh berat badan lahir bayi berkisar antara 2500 gram sampai 4000 gram.

3. Rumus SML (Subagio, Masengi, Loho) memiliki ketepatan taksiran berat badan lahir lebih baik dibandingkan dengan rumus Johnson Toshach, rumus modifikasi Johnson menurut Syahrir dan rumus Niswander. Ini terlihat dari hasil taksiran berat badan lahir berdasarkan rumus SML (Subagio, Masengi, Loho) yang menunjukkan ketepatan baik sebesar $73.47 \%$.

4. Terdapat perbedaan yang signifikan antara berat badan lahir dengan rumus modifikasi Johnson menurut Syahrir dan rumus Niswander, sedangkan tidak terdapat perbedaan yang signifikan antara berat badan lahir dengan rumus Johnson Toshach dan rumus SML (Subagio, Masengi, Loho).

5. Rumus SML (Subagio, Masengi, Loho) adalah yang terdekat dengan berat badan lahir bayi. 


\section{DAFTAR PUSTAKA}

Adenine, Iwan. 2006. Perkembangan janin \& Pengawasan ibu hamil dengan USG. Tersedia di http://rsiatambak.com.

Affandi, Biran. 2012. Kehamilan Ideal Usia 20-35 Tahun. Tersedia di http://health.kompas.com/read/2012 /09/27/07455176/Kehamilan.Ideal.U sia.20-35.Tahun.

Anonim. 2012. Tabel Pekembangan Janin \& Ibu Hamil. Tersedia di http://www.infobunda.com/pages/ba dan/index.php.

Arikunto, Suharsimi. 2000. Prosedur Penelitian Pendekatan Praktek. Edisi Revisi V. Jakarta: Rineka Cipta.

Arikunto, Suharsimi. 2006. Prosedur Penelitian: Suatu Pendekatan Praktik. Jakarta: Rineka Cipta.

Bobak, Lowdermilk, Jansen. 2005. Buku Ajar Keperawatan Maternitas. Edisi 4. Jakarta: EGC.

Budiarto, Eko. 2004. Metode Penelitian. Jakarta: EGC.

Cunningham, F. Hartono, Andry. 2006. Obstetri William.Jakarta: EGC.

Depkes RI. 2005. Materi ajar upaya penurunan kematian ibu dan bayi baru lahir. Kerjasama DepkesFKMUI.

Depkes RI. 2008. Asuhan Persalinan Normal. JNPK-KR. Jakarta.

Ghozali, Imam. 2009. Aplikasi Analisis Multivariate dengan Program SPSS. Semarang: BP UNDIP.

Hidayat, A. A. 2009. Metode Penelitian Keperawatan dan Tekhnik Analisis Data. Jakarta: Salemba Medika.

Julianty K., Yola N., Azis Z., Pangemanan T.P., $\quad$ Theodorus. 2006. Perbandingan Akurasi Taksiran Berat Badan Janin Menggunakan Rumus Johnson Tohsach Dengan Modifikasi Rumus Johnson Menurut Syahrir. Tersedia di http://www.beri- beri.com/2009/08/materi-kesehatantaksiran-berat-badan.html.

Melinda. 2010. Tinggi Badan Ibu Hamil Mempengaruhi Kesehatan Bayi. Tersedia di http://www.melindahospital.com/mo dul/user/detail_artikel.php?id=628_ Tinggi-Badan-Ibu-HamilMempengaruhi-Kesehatan-Bayi.

Niswander K.R., Capraro V.J., Coevering R.J. 1970. Estimation Of Birth Weight By Quantitied External Uterine Measurements. Obstet Gynecol; 36:204-8.

Noor, Hanif M. 2010. Pemeriksaan Obstetrik. Tersedia di http://ilmudokteraurora.blogspot.com/2010/01/pemer iksaan-obstetrik.html.

Notoatmodjo, Sukidjo, 2005. Metodologi Penelitian Kesehatan. Jakarta: Rineka Cipta.

Nursalam. 2008. Konsep dan Penerapan Metodologi Penelitian Ilmu Keperawatan. Jakarta: Salemba Medika.

Panero, Julius dan Zelnik, Martin. 2003. Dimensi manusia dan ruang interior. Jakarta: Erlangga.

Prasetyowati, Firda Fibrila dan Martini. 2009. Perbandingan Hasil Tafsiran Berat Janin Menurut Johnson Tohsach dan Niswander Dengan Berat Badan Lahir Pada Ibu Inpartu di BPS Kab. Lampung Utara. Lampung.

Prawirohardjo, Sarwono. 2007. Ilmu Kebidanan. Jakarta: Yayasan Bina Pustaka Sarwono Prawirohardjo.

Rachmawati, I.N., Budiati, T., Rahmawati, C. 2008. Panduan Praktikum Prosedur Pemeriksaan Fisik Antenatal. Depok.

Rochjati, Poedji, 2003. Skrining Antenatal pada Ibu Hamil. Surabaya: Airlangga University Press.

Rosmina S., Masengi J.A., Taniowas Loho M. 2001. Perbandingan Ketepatan Mengestimasi Berat 
Badan Lahir Menurut Rumus Johnson dan Rumus SML. Tesis Bagian Obstetri dan Ginekologi FK UNSRAT/RSUP Manado. Manado.

Rustiadi, Tri. 2012. Bagaimana Cara Mengukur Tinggi dan Berat Badan Ideal?. Tersedia di http://senamaerobic.wordpress.com/ 2012/04/14/bagaimana -caramengukuran-tinggi-dan-beratbadan-ideal/.

Sarmun, Budi. 2012. Tinggi, Angka Kematian Bayi di Indonesia. Tersedia di

http://www.suaramerdeka.com/v1/index.p hp/read/news/2012/06/06/120534/Ti nggi-Angka-Kematian-Bayi-diIndonesia.

Subagio P., Masengi J.A., Taniowas Loho M. 2000. Hubungan Berat Badan Lahir dengan Jarak Simfisis Fundus dan Beberapa Anthropometri Ibu. Tesis Bagian Obstetri dan Ginekologi FK UNSRAT/RSUP Manado. Manado.

Suparyanto. 2012. Berat Bayi Lahir. Tersedia di http://infokesehatanhealthy.blogspot.com/2012/03/berat -bayi-lahir.html.

Sylviati. 2008. Klasifikasi Bayi Menurut Berat Lahir dan Masa Gestasi. In: Sholeh Kosim, dkk. Buku Ajar Neonatologi. Jakarta: Badan Penerbit IDAI, 11-30.

Wijaya, Awi Mulyadi. 2009. Kondisi Angka Kematian Neonatal, Bayi, dan Balita di Indonesia. Tersedia di http://www.scribd.com/doc/4966029 5/SDKI-2007.

Wiknjosastro, H dan Saifuddin, A. B. 2005. Ilmu Kebidanan. Jakarta: Yayasan Bina Pustaka Sarwono Prawirohardjo.

Wulandari, Yulia. 2008. Pengukuran Tinggi Fundus Uteri._Tersedia di http://www.akbidyspsdmi.net.

Yurisa, Wella. 2008. Etika Penelitiian Kesehatan. Pekanbaru, Riau:
Faculty of Medicine - University of Riau.

Zaini. 2012. Pemeriksaan Kehamilan. Tersedia di http://bidanku.com/index.php?/peme riksaan-kehamilan. 